\title{
Patients Presenting in Intensive Care Unit of Nepal Police Hospital: An Overview
}

\author{
A B Hamal ${ }^{1 *}$, Sundar Hyoju ${ }^{2}$, Suraj Rana ${ }^{3}$ and Jharana Shah ${ }^{4}$ \\ ${ }^{1,3}$ Consultant Physician, Nepal Police Hospital, Nepal \\ ${ }^{2}$ Consultant Anesthesiologist, Nepal Police Hospital, Nepal \\ ${ }^{4}$ Lecturer \& Coordinator, Kantipur Academy of Health Sciences
}

Submission: July 15, 2019; Published: August 02, 2019

*Corresponding author: A B Hamal, Consultant Physician, Nepal Police Hospital, Maharajgunj, Kathmandu, Nepal

\begin{abstract}
Objective of the study: To study the causes of Intensive care Unit (ICU) admission of patients in Nepal Police hospital (NPH) and their outcomes.

Methodology: This is retrospective cohort study. All the data about the ICU patients admitted in NPH in the year 2015/016 were taken into account.

Observations and results: The highest numbers of patients in ICU were the family members (48\%) followed by in service patients and the retired ones. The total mortality in ICU was 49 (32.3\%). Most of the patients were suffering from the respiratory problems (28.9\%), followed by renal failure (15\%), upper gastrointestinal bleeding (13.8\%), strokes (8.5\%), diabetes with complications $(6.6 \%)$ and also the patients with postoperative sepsis, etc. There were total four cases of poisoning and one case of HSV encephalitis and tubercular meningitis each who survived after being treated. There were altogether 18 patients who needed invasive mechanical ventilation. The survival rate after invasive mechanical ventilation is $38.8 \%$. Finally, total bed occupancy rate in ICU (From Feb $5^{\text {th }} 2015$ to $12^{\text {th }}$ Feb 2016 was 63\%).

Conclusion: Thus, Intensive Care Unit of Nepal Police Hospital is an important entity for the care and treatment of seriously ill patients. Serving critically ill patients is a challenge and it needs patience, hard work and adequate counseling to the patient party which can be followed in other government hospitals too where ICU treatment has not been started yet.
\end{abstract}

Keywords: Intensive Care Unit (ICU); Nepal Police Hospital (NPH)

\section{Introduction}

Nepal Police Hospital was inaugurated by the late king Birendra Bir Bikram Shah Dev on the $9^{\text {th }}$ April 1984. It was established with an intention to provide free health services to in- service policemen, their families and ex-servicemen and their spouses. The hospital commenced OPD services and 25 bedded indoor services through 5 medical doctors, a few nurses, paramedics and administrative staff.

When there is a need to manage and monitor patients with life threatening conditions, a separate self-equipped and staffed unit in a hospital is a must that is termed as Intensive Care Unit (ICU).

The uninterrupted ICU service was started in NPH since $5^{\text {th }}$ February 2015. There are 5 beds in ICU. Being established for more than 30 years, this hospital has just started crawling with ICU services. This is one of the open ICUs in Nepal.

The term "ICU" in Nepal refers to a separate area in the hospital identified to admit critically ill patients requiring life support including inotropes / vasopressors and or mechanical ventilators [1].

In Nepal, the first ICU started in 1973 at Bir Hospital, as a fivebed medical ICU. This ICU was established in 1970 when King Mahendra Bir Bikram Shah Dev developed heart problem [2]. After establishment of Tribhuvan University Teaching Hospital (TUTH) at Institute of Medicine (IOM), Maharajgunj in 1990, second ICU in the country came into function as six- bed mixed medical surgical beds ICU [3]. This number of ICU beds in TUTH has been increased to more than 15 in recent years.

Almost all hospitals in the country including different medical colleges and teaching hospitals still have few 'ICU beds' accounting to a total of around 500 ICU beds in the country. The services, standard, outcomes and efficiency of these ICUs have rarely been published, except for very few hospitals $[4,5]$.

Almost a decade ago a survey published about ICU capacity 
and resources in Nepal within the Kathmandu Valley included 51 hospitals from a list of ' $50+$ ' bed capacity obtained from Ministry of Health. Out of these, 11 (21.6\%) were Government Hospitals, 8 (15.7\%) were Community Hospitals and 32 (62.7\%) were Private Hospitals and only 33 (64.7\%) of hospitals have ICU facilities [6]. Almost all ICUs in Nepal are 'Open ICUs' and currently Internists and Anesthesiologists are managing patients [1].

Florence Nightingale after the Crimean war had put forward the concept of Intensive care units when she started treating sicker patients in a separate area in the hospital and later, during World War II, these areas were established as 'shock wards'. These wards were used to resuscitate and treat the injured soldiers $[7,8]$.

In John Hopkins Hospital, the first multidisciplinary ICU started functioning only in 1958 providing care 24 hours a day. This was the first ICU to be covered by an in-site physician mechanically ventilated was also taken. (anesthesia resident) 24 hour a day and 365 days a year [8]. However, now the concept of ICU has widened its territory in terms of human resources and services including diagnostic and therapeutic interventions.

\section{Significance of the study}

The study about the patients' clinical profile and their outcomes has been studied very less in Nepal. This study will help to identify the potential cases that are mostly admitted in ICU of Nepalese hospitals. The outcomes of those patients and the improvement in their survival could also be identified.

\section{Methodology}

All the data about the ICU patients admitted in NPH in the year 2015/016 were taken into account. The outcome of those patients was analyzed. Also, the survival of the patients who got

Table 1: Total ICU admission.

\begin{tabular}{|c|c|c|c|c|c|}
\hline Category & Admission & \% of Cases & Mortality & Mortality\% & LAMA* Left against Medical Advice \\
\hline Inservice & 40 & $26.40 \%$ & 11 & $27.50 \%$ & 1 \\
\hline Retired & 39 & $25.60 \%$ & 10 & $25.60 \%$ & \\
\hline Family & 73 & $48 \%$ & 27 & $37.90 \%$ & \\
\hline Total & 152 & & 49 & $32.30 \%$ & \\
\hline
\end{tabular}

Table 2:Causes of ICU admission.

\begin{tabular}{|c|c|c|c|c|c|}
\hline Sn & Diagnosis & Inservice & Retired & Family & Total \\
\hline 1 & Pneumonia with sepsis & 3 & 1 & 7 & 11 \\
\hline 2 & COPD with Resp failure & 0 & 6 & 27 & 33 \\
\hline 3 & Alcohol withdrawal synd & 3 & 0 & 0 & 3 \\
\hline 4 & Malignancies & 3 & 0 & 5 & 8 \\
\hline 5 & Decompensated Liver Cirrhosis with UGI bleeding & 5 & 12 & 4 & 21 \\
\hline 6 & Renal Failure & 3 & 7 & 13 & 23 \\
\hline 7 & Stroke & 2 & 3 & 8 & 13 \\
\hline 8 & Diabetes with complications & 3 & 6 & 1 & 10 \\
\hline 9 & Poisoning & 4 & 0 & 0 & 4 \\
\hline 10 & Acute Encephalitis/ Meningitis & 2 & 0 & 0 & 2 \\
\hline 11 & Postoperative sepsis & 2 & 2 & 5 & 9 \\
\hline 12 & $\begin{array}{l}\text { Others (Tuberculosis, Assault, Hypertension, Ischemic Heart Disease, } \\
\text { Hematological, etc) }\end{array}$ & 10 & 2 & 3 & 15 \\
\hline Total & 40 & 39 & 73 & 152 & \\
\hline
\end{tabular}

The highest numbers of patients in ICU were the family members (48\%) followed by in service patients and the retired ones (Table 1). The mortality number was 49 (32.3\%) and one left against medical advice. Most of the patients were suffering from the respiratory problems (28.9\%), followed by renal failure
(15\%), upper gastrointestinal bleeding (13.8\%), strokes $(8.5 \%)$, diabetes with complications $(6.6 \%)$ and also the patients with postoperative sepsis, etc. There were total four cases of poisoning and one case of HSV encephalitis and tubercular meningitis each who survived after being treated (Table 2). 
Table 3:Gender distribution.

\begin{tabular}{|c|c|c|c|c|}
\hline Gender & Inservice & Retired & Family & Percentage (\%) \\
\hline Male & 39 & 30 & 41 & 110 \\
\hline Female & 1 & 9 & 32 & $42.40 \%$ \\
\hline Total & 40 & 39 & 73 & $27.60 \%$ \\
\hline
\end{tabular}

Among admitted patients in ICU $72.4 \%$ were male patients and rest of them were female (Table 3).

Also, it was seen that $38.8 \%$ of patients who needed invasive mechanical ventilation were finally extubated (Table 4). Thus, total bed occupancy rate (From Feb $5^{\text {th }}, 2015$ to $12^{\text {th }}$ Feb 2016): 1184/1865: 63\%.

Table 4: Mechanically ventilated patients.

\begin{tabular}{|c|c|c|c|}
\hline Category & Mechanically Ventilated Patients & Extubated & Percentage \% (Survival) \\
\hline In service & 7 & 4 & $57.10 \%$ \\
\hline Retired & 3 & 1 & $33.30 \%$ \\
\hline Family & 8 & 2 (LAMA =1) & $25 \%$ \\
\hline Total & 18 & 7 & $38.80 \%$ \\
\hline
\end{tabular}

\section{Discussion}

It was seen that the majority of patients admitted in ICU included the family members of police personnel. Male patients were more than the female among the admitted. Most of the patients were suffering from the respiratory problems $(28.9 \%)$, followed by renal failure (15\%), upper gastrointestinal bleeding (13.8\%), strokes (8.5\%), diabetes with complications $(6.6 \%)$ and few with postoperative sepsis.

The overall mortality was $32.3 \%$ and among the ventilated patients $38.8 \%$ were extubated and survived. This can be compared with the study done by Msosche et al. [9] in which in hospital mortality was $74 \%$ in mechanically ventilated patients.

Also, in the study done by Andries Esteban et al. [10] the overall mortality in ICU was $30.7 \%$. Among those who needed mechanical ventilation due to acute respiratory distress syndrome and for exacerbation of Chronic Obstructive Pulmonary Diseases, $52 \%$ and $22 \%$ patients had mortality respectively.

\section{Conclusion}

Thus Intensive Care Unit of Nepal Police Hospital is an important entity for the care and treatment of seriously ill patients. It is necessary to decorate it with adequate equipments and human resources. Serving critically ill patients is a challenge and it needs patience, hard work and adequate counseling to the patient party which can be followed in other government hospitals too where ICU treatment has not been started yet.

\section{References}

1. Acharya SP (2014) Critical Care Medicine: An emerging superspeciality in Nepal. Journal of Society of Anesthesiologists of Nepal 1(2): 55-58.

2. Marasini BR (2003) Health and Hospital Development in Nepal, Past and Present. JNMA 42(149): 306-311.

3. Acharya SP (2013) Critical Care medicine in Nepal: where are we? International Health 5(2): 92-95.

4. Sharma NR (2005) Outcome of intubated post-surgical cases in intensive care unit in Tribhuvan university teaching hospital, Nepal. Journal of Institute of Medicine 27(3): 29-30.

5. Koirala S, Ghimire A, Sharma A, Bhattarai B (2011) ICU admission and outcomes in a community-based tertiary care hospital: an audit of one year. Health Renaissance 9(2): 83-87.

6. Shrestha RR, Vaidya PR, Bajracharya GR (2011) A survey of adult intensive care units in Kathmandu Valley. Postgrad Med J NAMS 11(2): $1-7$.

7. Berthelsen PG, Cronqvist M (2003) The first intensive care unit in the world: Copenhegan 1953. Acta Anaesthesiol Scan 47(10): 1190-1195.

8. Pincock S (2007) Bjorn Aage Ibsen. The Lancet 370(9598): 1538.

9. Hersch M, Izbicki G, Dahan D, Breuer GS, Nesher G, et al. (2012) Predictors of mortality of mechanically ventilated patients in Internal Medicine wards. Journal of Critical Care 27(6): 694-701.

10. Esteban A, Anzueto A, Frutos F, Alía I, Brochard L, et al. (2002) Characteristics and outcomes in adult patients receiving mechanical ventilation A 28-day International Study. JAMA 287(3): 345-355. 
This work is licensed under Creative Commons Attribution 4.0 License

DOI: 10.19080/JAICM.2019.09.555758
Your next submission with Juniper Publishers will reach you the below assets

- Quality Editorial service

- Swift Peer Review

- Reprints availability

- E-prints Service

- Manuscript Podcast for convenient understanding

- Global attainment for your research

- Manuscript accessibility in different formats ( Pdf, E-pub, Full Text, Audio)

- Unceasing customer service

Track the below URL for one-step submission https://juniperpublishers.com/online-submission.php 